\title{
MULTI AKAD (AL-UQUD AL-MURAKKABAH) DI PERBANKAN SYARIAH PERSPEKTIF FIQH MUAMALAH
}

\author{
Yosi Aryanti \\ Jurusan Pendidikan Agama Islam STIT Ahlussunnah Bukittinggi \\ J1. Diponegoro No. 8 Ateh Tambuo Aur Kuning Bukittinggi. Telp. (0752) 34130 \\ e-mail: ochies1978@gmail.com
}

\begin{abstract}
Multiple Agreement (al-Uqud al-Murakkabah) is one of contemporary agreements in Islamic banking whose implementation develops in line with business developments Multiple Agreement basically is an agreement whic is made by two parties in carrying out transactions that cover two elements or more of agreement, such as trading and ijarah. Agreements in sharia transactions are modified from the existing agreements in which such agreements are found in almost all sharia products. The development of the uses of agreement need strong analysis concerning the validity of the agreements, especially those whic have been modified. This study therefore aims at presenting perspectives of Islamic schlars (ulama) and their analysis toward the concepts of Multiple Agreement.
\end{abstract}

Kata kunci: akad, multi akad, perbankan syariah

\section{PENDAHULUAN}

$\mathcal{P}$ ertumbuhan ekonomi syariah ditandai dengan meningkatnya jumlah Perbankan Syariah serta model produk yang ditawarkan. Pertumbuhan perbankan syariah tergolong paling cepat dibanding lembaga keuangan syariah lainnya, seperti asuransi syariah, pegadaian syariah, pembiayaan syariah, dan pasar modal syariah (Bank Indonesia, 2013:1).

Pertumbuhan Perbankan Syariah ditandai dengan munculnya produk- produk kreatif yang ditawarkan kepada masyarakat. Penawaran produk-produk baru tersebut sebagai salah satu strategi pemasaran untuk meningkatkan nasabah di tengah persaingan Perbankan yang semakin terbuka

Perkembangan perbankan syariah di Indonesia saat ini, menuntut para praktisi, regulator, dan bahkan akademisi bidang keuangan syariah untuk senantiasa aktif dan kreatif dalam rangka memberikan respon terhadap perkembangan tersebut. Para praktisi dituntut melakukan penciptaan berbagai produk, regulator membuat regulasi yang mengatur dan mengawasi produk yang ditawarkan dan laksanakan oleh praktisi, dan akademisi pun dituntut memberikan pencerahan dan tuntunan agar produk maupun regulasi benar-benar tidak menyimpang dari prinsip-prinsip syariah.

Munculnya produk-produk baru di Perbankan Syariah menimbulkan kesulitan dalam penerapan prinsip syariah terutama dalam aspek kesesuaiannya dengan akad. Ijtihad para ulama sangat diperlukan dalam menjawab persoalan tersebut. Dewan Syariah Nasional telah berupaya memberikan jawaban terhadap kebutuhan produk tersebut yang tersebar dalam fatwa DSN. Sebagian fatwa terbut merupakan transformasi akad-akad dalam hukum Islam ke dalam kegiatan transaksi keuangan modern.

Untuk menilai suatu produk apakah telah memenuhi prinsip syariah atau tidak, salah satunya adalah dengan memperhatikan akadakad dan berbagai ketentuannya yang 
digunakan dalam produk tersebut. Produkproduk dalam perbankan syariah, beberapa atau bahkan sebagian terbesar ternyata mengandung beberapa akad. Sebagai contoh, dalam transaksi kartu kredit syariah terdapat akad ijarah, qardh, dan kafalah, obligasi syariah mengandung sekurang-kurangnya akad mudharabah (atau ijarah) dan wakalah, serta terkadang disertai kafalah.

Dalam setiap transaksi, akad-akad tersebut dilakukan secara bersamaan atau setidaktidaknya setiap akad yang terdapat dalam suatu produk tidak bisa ditinggalkan, karena kesemuanya merupakan satu kesatuan. Transaksi seperti itulah yang dalam tulisan ini diistilahkan dengan "Multi Akad" yang kini dalam peristilahan fikih muamalat kontemporer (figh al-mu'amalat al-maliyah al-mu'ashirah) disebut dengan al-'uqud al-murakkabah.

Multi akad adalah kesepakatan dua pihak untuk melaksanakan suatu transaksi yang meliputi dua akad atau lebih, sehingga semua akibat hukum dari akad gabungan itu serta semua hak dan kewajiban yang ditimbulkannya dianggap satu kesatuan yang tidak dapat dipisahkan. Dengan banyaknya transaksi modern yang menggunakan multi akad sebagaimana disinggung di atas, kini atau bahkan pada dasawarsa terakhir ini mulai ramai diperbincangkan para pakar fikih sekitar keabsahan dari multi akad.

Perbincangan dan perdebatan mengenai keabsahan multi akad ini muncul bukan tanpa sebab. Sejumlah Hadis Nabi -sekurangnya tiga buah Hadis-secara lahiriah (ma'na zhahir)menunjukkan larangan penggunaan multi akad. Misalnya, Hadis tentang larangan untuk melakukan bai' dan salaf, larangan bai'ataini fi bai'atin, dan shafqataini fi shafqatin. Dengan adanya hadis-hadis tersebut kiranya sangat wajar jika timbul pertanyaan, apakah produk-produk di perbankan syariah yang menggunakan multi akad dapat dipandang memenuhi prinsip syariah atau sebaliknya. apa dan bagaimana sebenarnya konsep multi akad, multi akad seperti apa yang memenuhi prinsip syariah, dan tentu saja apa yang dimaksudkan oleh Nabi dengan Hadis-hadisnya tersebut.

\section{PEMBAHASAN}

\section{Pengertian Multi Akad}

Kata akad berasal dari bahasa Arab berarti mengikat, menetapkan, membangun, (Louis Ma'luf, 1986: 518) dan lawan dari melepaskan تنب الحل Kata akad berarti juga perikatan atau janji . Kata akad sudah diserap dalam bahasa Indonesia yang secara secara etimologi artinya mengokohkan, meratifikasi dan mengadakan perjanjian (Ahmad Warson Munawir, 1997: 953). Sedangkan secara terminologi akad berarti mengadakan perjanjian atau ikatan yang mengakibatkan munculnya kewajiban. (Louis Ma'luf, 1986 : 519). Menurut Wahbah az-Zuhaili, akad adalah pertalian atau perikatan antara ijab dan qabul sesuai dengan kehendak syariah yang menetapkan adanya akibat hukum pada objek perikatan" (Wahbah al-Zuhaily, 2006: 2917).

Dalam hukum Indonesia, akad di artikan dengan perjanjian. Sedangkan dalam istilah hukum Islam, ada beberapa definisi yaitu:

1. Akad berarti keterkaitan antara ijab (pernyataan penawaran atau pemindahan kepemilikan) dan qabul (pernyataan penerimaan kepemilikan) dalam lingkup yang disyariatkan dan berpengaruh pada sesuatu.

2. Menurut pendapat ulama Syafi'iyah, Malikiyah dan Hanabilah, yaitu segala sesuatu yang dikerjakan oleh seseorang berdasarkan keinginannya sendiri, seperti waqaf, talak, pembebasan, atau sesuatu yang pembentukannya membutuhkan keinginan dua orang seperti jual beli, perwakilan, dan gadai

3. Akad merupakan pertemuan ijab yang diajukan oleh salah satu pihak dengan kabul 
dari pihak lain yang menimbulkan akibat hukum pada objek akad.

Terkait dengan akad ini, Shubhy Mahmashany, membagi perbuatan hukum atas harta dalam dua bentuk, pertama disebut dengan akad, yaitu sesuatu kegiatan yang membutuhkan kesepakatan dua belah pihak atau lebih. Kedua, suatu kegiatan dapat terjadi cukup dari kehendak sepihak saja. Termasuk dalam kelompok pertama adalah jual beli, sewa menyewa, salam, dan yang lainnya. Termasuk dalam kelompok kedua adalah: perbuatan tambahan dalam hukum keluarga dan syarat, nazar dan sumpah, yang berhubungan dengan masalah ibadah adalah pembatalan dalam hukum keluarga, seperti perceraian, pembebasan budak dan lainnya; wakaf dan wasiat dan pembebasan hutang, pembatalan, dan kafâlah (Subhy Mahmashany, 1983: 262)

Multi dalam bahasa Indonesia berarti banyak (lebih dari satu) dan berlipat ganda ( Tim Penyusun, 1996: 671). Dengan demikian, multi akad dalam bahasa Indonesia berarti akad berganda atau akad yang banyak, lebih dari satu. Sedangkan menurut istilah figh kata multi akad merupakan terjemahan dari kata Arab yaitu al'uqûd al-murakkabah yang berarti akad ganda (rangkap). Al-'uqûd al-murakkabah terdiri dari dua kata al-'uqûd (bentuk jamak dari 'aqd) dan al-murakkabah.

Kata al-murakkabah (murakkab) secara etimologi berarti al-jam'u (mashdar), yang berarti pengumpulan atau penghimpunan (Ahmad Warson Munawir, 1997: 209). Kata murakkab sendiri berasal dari kata "rakkaba-yurakkibutarkîban" yang mengandung arti meletakkan sesuatu pada sesuatu yang lain sehingga menumpuk, ada yang di atas dan yang di bawah. Sedangkan murakkab menurut pengertian para ulama fikih mengandung beberapa pemahaman, diantaranya pertama berarti himpunan beberapa hal sehingga disebut dengan satu nama. Seseorang menjadikan beberapa hal menjadi satu hal (satu nama) dikatakan sebagai melakukan penggabungan (tarkîb), kedua berrati sesuatu yang dibuat dari dua atau beberapa bagian, sebagai kebalikan dari sesuatu yang sederhana (tunggal/basith) yang tidak memiliki bagian-bagian, ketiga berarti meletakkan sesuatu di atas sesuatu lain atau menggabungkan sesuatu dengan yang lainnya. (al-'Imrani, 2006: 45)

Ketiga pengertian ini memiliki kelebihan dan kekurangan masing-masing untuk menjelaskan makna persis dari istilah murakkab. Pengertian pertama lebih tepat untuk digunakan karena mengandung dua hal sekaligus, yaitu terhimpunnya beberapa hal dan bersatunya beberapa hal itu yang kemudian menjadi satu pengertian tertentu. Pengertian kedua tidak menjelaskan akibat dari terhimpunnya beberapa hal itu. Meski pengertian kedua menyatakan adanya gabungan dua atau beberapa hal, tetapi tidak menjelaskan apa dan bagaimana setelah terjadi penggabungan tersebut. Pengertian terakhir lebih dekat kepada pengertian etimologis, tidak menjelaskan pengertian untuk suatu istilah tertentu. Dengan demikian pengertian pertama lebih dekat dan pas untuk menjelaskan maksudal-'uqûd al-murakkabah dalam konteks fikih muamalah.

Berdasarkan pemahaman tentang makna akad dan multi (murakkab) , maka multi akad menurut Nazih Hammad adalah kesepakatan dua pihak untuk melaksanakan suatu akad yang mengandung dua akad atau lebih sepertijual beli dengan sewa menyewa, hibah, wakalah, gardh, muzara'ah, sahraf (penukaran mata uang), syirkah, mudharabah dan seterusnya. Sehingga semua akibat hukum akad-akad yang terhimpun tersebut, serta semua hak dan kewajiban yang ditimbulkannya dipandang sebagai satu kesatuan yang tidak dapat dipisah-pisahkan, sebagaimana akibat hukum dari satu akad. (Nazzih Hamaad, 2005: 7).

Sedangkan menurut Al-Imrani, multi akad adalah Himpunan beberapa akad 
$180 \|$ Jurnal Imiah Sygri'ah, Volume l5, Nomor 2, Juli-Desember 20016

kebendaan yang dikandung oleh sebuah akad baik secara gabungan maupun secara timbal balik sehingga seluruh hak dan kewajiban yang ditimbulkannya dipandang sebagai akibat hukum dari satu akad. (Al-Imrani, 2006: 47)

\section{Macam-macam Multi Akad}

Al-'Imrani membagi multi akad dalam lima macam, yaitu al-'uqûd al-mutaqâbilah, al'uqûd al-mujtami'ah, al-'uqûd al-mutanâqidhah wa al-mutadhâdah wa al-mutanâfiyah, al-'uqûd al-mukhtalifah, al-uqûd al-mutajânisah. Dari lima macam itu, menurutnya, dua macam yang pertama; al-'uqûd al-mutaqâbilah, al-'uqûd almujtami'ah, adalah multi akad yang umum dipakai.

\section{Akad Bergantung/Akad Bersyarat (al-'Uqûd al- Mutaqâbilah)}

Al-Mutaqâbilah menurut bahasa berarti berhadapan. Sesuatu dikatakan berhadapan jika keduanya saling menghadapkan kepada yang lain. Sedangkan yang dimaksud dengan al-'uqûd al-mutaqâbilah adalah multi akad dalam bentuk akad kedua merespon akad pertama (Imam Malik,1323 H:126) di mana kesempurnaan akad pertama bergantung pada sempurnanya akad kedua melalui proses timbal balik. Dengan kata lain, akad satu bergantung dengan akad lainnya. Dalam tradisi fikih, model akad seperti ini sudah dikenal lama dan praktik- nya sudah banyak. Banyak ulama telah membahas tema ini, baik yang berkaitan dengan hukumnya, atau model pertukarannya. Misalnya antara akad pertukaran (mu'âwwadhah) dengan akad tabarru', antara akad tabarru' dengan akad tabarru' atau akad pertukaran dengan akad pertukaran. Ulama biasa mendefinisikan model akad ini dengan akad bersyarat (isytirâth 'aqd bi 'aqd) (Al-Imrani, 2006:57).

\section{Akad Terkumpul (al-'Uqûd al-Mujtami'ah)}

Al-'uqûd al-mujtami'ah adalah multi akad yang terhimpun dalam satu akad. Dua atau lebih akad terhimpun menjadi satu akad. Misalnya "saya jual rumah ini kepadamu dan saya sewakan rumah yang lain kepadamu selama satu bulan dengan harga lima ratus ribu". Multi akad yang mujtami'ah ini dapat terjadi dengan terhimpunnya dua akad yang memiliki akibat hukum berbeda di dalam satu akad terhadap dua objek dengan satu harga, dua akad berbeda akibat hukum dalam satu akad terhadap dua objek dengan dua harga, atau dua akad dalam satu akad yang berbeda hukum atas satu objek dengan satu imbalan, baik dalam waktu yang sama atau waktu yang berbeda.

\section{Akad Berlawanan (al-Uqû̂d al-Mutanâqidhah wa al-Mutadhâdah wa al-Mutanâfiyah)}

Ketiga istilah al-mutanâqidhah, almutadhâdah, al-mutanâfiyah memiliki kesamaan bahwa ketiganya mengandung maksud adanya perbedaan. Tetapi ketiga istilah ini mengandung implikasi yang berbeda. Mutanâqidhah mengandung arti berlawanan, seperti pada contoh seseorang berkata sesuatu lalu berkata sesuatu lagi yang berlawanan dengan yang pertama. Seseorang mengatakan bahwa sesuatu benar, lalu berkata lagi sesuatu itu salah. Perkataan orang ini disebut mutanâqidhah, saling berlawanan. Dikatakan mutanâqidhah karena antara satu dengan yang lainnya tidak saling mendukung, melainkan mematahkan.

\section{AkadBerbeda (al-'Uqûud al-Mukhtalifah)}

Yang dimaksud dengan multi akad yang mukhtalifah adalah terhimpunnya dua akad atau lebih yang memiliki perbedaan semua akibat hukum di antara kedua akad itu atau sebagiannya. Seperti perbedaan akibat hukum dalam akad jual beli dan sewa, dalam akad sewa diharuskan ada ketentuan waktu, sedangkan dalam jual beli sebaliknya. Contoh lain, akad ijârah dan salam. Dalam salam, harga salam harus diserahkan pada saat akad (fi al-majlis), sedangkan dalam ijârah, harga sewa tidak harus diserahkan pada saat akad. 
Perbedaan antara multi akad yang mukhtalifah dengan yang mutanâqidhah, mutadhâdah, dan mutanâfiyah terletak pada keberadaan akad masing-masing. Meskipun kata mukhtalifah lebih umum dan dapat meliputi ketiga jenis yang lainnya, namun dalam mukhtalifah meskipun berbeda tetap dapat ditemukan menurut syariat. Sedangkan untuk kategori berbeda yang ketiga mengandung adanya saling meniadakan di antara akad-akad yang membangunnya. Dari perbedaan di atas bisa dipahami bahwa multi akad yang mutanâqidhah, mutadhâdah, dan mutanâfiyah adalah akad-akad yang tidak boleh dihimpun menjadi satu akad. Meski demikian pandangan ulama terhadap tiga bentuk multi akad tersebut tidak seragam.

\section{Akad Sejenis (al-'Uqûd al-Mutajânisah)}

Al-'uqûd al-murakkabah al-mutajânisah adalah akad-akad yang mungkin dihimpun dalam satu akad, dengan tidak memengaruhi di dalam hukum dan akibat hukumnya. Multi akad jenis ini dapat terdiri dari satu jenis akad seperti akad jual beli dan akad jual beli, atau dari beberapa jenis seperti akad jual beli dan sewa menyewa. Multi akad jenis ini dapat pula terbentuk dari dua akad yang memiliki hukum yang sama atau berbeda.

\section{Batasan dan Standar Multi Akad}

Para ulama yang membolehkan praktik multi akad bukan berarti membolehkan secara bebas, tetapi ada batasan-batasan yang tidak boleh dilewati. Karena batasan ini akan menyebabkan multi akad menjadi dilarang. Di kalangan ulama, batasan-batasan ini ada yang disepakati dan diperselisihkan. Secara umum, batasan yang disepakati oleh para ulama adalah sebagai berikut:

\section{Multi Akad Dilarang karena Nash Agama}

Dalam Hadis Nabi secara jelas menyatakan tiga bentuk multi akad yang dilarang, yaitu multi akad dalam jual beli $\left(b a^{\prime} i\right)$ dan pinjaman, dua akad jual beli dalam satu akad jual beli dan dua transaksi dalam satu transaksi. Dalam sebuah hadis disebutkan.

$$
\text { هى رسول الله صلى الله عليه و سلم عن ييع وسلف }
$$

Rasulullah Saw melarang jual beli dan pinjaman. (HR Ahmad dari Abu Hurairah Ra.,)

Suatu akad dinyatakan boleh selama objek, harga, dan waktunya diketahui oleh kedua belah pihak. Jika salah satu di antaranya tidak jelas, maka hukum dari akad itu dilarang. Ibnu Qayyim berpendapat bahwa Nabi melarang multi akad antara akad salaf (memberi pinjaman/qardh) dan jual beli, meskipun kedua akad itu jika berlaku sendiri-sendiri hukumnya boleh. Larangan menghimpun salaf dan jual beli dalam satu akad untuk menghindari terjurumus kepada riba yang diharamkan. Hal itu terjadi karena seseorang meminjamkan (qardh) seribu, lalu menjual barang yang bernilai delapan ratus dengan harga seribu. Dia seolah memberi seribu dan barang seharga delapan ratus agar mendapatkan bayaran dua ribu. Di sini ia memperoleh kelebihan dua ratus. (lbnu alQayyim, t.th.: 153)

Selain multi akad antara salaf dan jual beli yang diharamkan, ulama juga sepakat melarang multi akad antara berbagai jual beli dan qardh dalam satu transaksi. Semua akad yang mengandung unsur jual beli dilarang untuk dihimpun dengan qardh dalam satu transaksi, seperti antara ijarâh dan qardh, salam dan qardh, sharf dan qardh, dan sebagainya. Meski penggabungan qardh dan jual beli ini dilarang, namun menurut al-'Imrâni tidak selamanya dilarang. Penghimpunan dua akad ini diperbolehkan apabila tidak ada syarat di dalamnya dan tidak ada tujuan untuk melipatkan harga melalui qardh. Seperti seseorang yang memberikan pinjaman kepada orang lain, lalu beberapa waktu kemudian ia menjual sesuatu kepadanya padahal ia masih 
dalam rentang waktu qardh tersebut. Yang demikian hukumnya boleh. Sedangkan larangan penghimpunan dua akad jual beli dalam satu akad jual beli didasarkan pada hadis Nabi yang berbunyi: "Dari Abu Hurairah, berkata: "Rasulullah s.a.w. melarang dua jual beli dalam satu jual beli". (HR Malik)

Dari beberapa pendapat ulama di atas, pendapat yang rajih dalam hal ini adalah pendapat yang mengatakan bahwa akad demikian menimbulkan ketidakjelasan harga dan menjerumuskan riba. Pada hakikatnya tidak terjadi akad jual beli dalam transaksi tersebut.

\section{Multi Akad sebagai Hîlah Ribâwi}

Multi akad yang menjadi hîlah ribawi dapat terjadi melalui kesepakatan jual beli 'înah atau sebaliknya dan hîlah ribâ fadhl.

\section{Al-'̂nah}

Contoh Akad dalam bentuk 'inah yang dilarang adalah menjual sesuatu dengan harga seratus secara cicil dengan syarat pembeli harus menjualnya kembali kepada penjual dengan harga delapan puluh secara tunai. Pada transaksi ini seolah ada dua akad jual beli, padahal nyatanya merupakan hîlah ribâ dalam pinjaman (qardh), karena objek akad semu dan tidak faktual dalam akad ini. Sehingga tujuan dan manfaat dari jual beli yang ditentukan syariat tidak ditemukan dalam transaksi ini. Ibnu al-Qayyim menjelaskan bahwa agama menetapkan seseorang yang memberikan qardh (pinjaman) agar tidak berharap dananya kembali kecuali sejumlah qardh yang diberikan, dan dilarang menetapkan tambahan atas qardh baik dengan hilah atau lainnya. Demikian pula dengan jual beli disyariatkan bagi orang yang mengharapkan memberikan kepemilikan barang dan mendapatkan harganya, dan dilarang bagi yang bertujuan ribâ fadhl atau ribâa nasa', bukan bertujuan pada harga dan barang. (lbnu al-Qayyim, tt: 250)

\section{Hîlah ribâf fadhl}

Hal ini terjadi apabila seseorang menjual sejumlah (misalnya $2 \mathrm{~kg}$ beras) harta ribawi dengan sejumlah harga (misalnya Rp 20.000) dengan syarat bahwa ia dengan harga yang sama (Rp 20.000) harus membeli dari pembeli tadi sejumlah harta ribawi sejenis yang kadarnya lebih banyak (misalnya 3 kilogram) atau lebih sedikit (misalnya 1 kilogram). Transaksi seperti ini adalah model hîlah ribâ fadhl yang diharamkan. Transaksi seperti ini dilarang didasarkan atas peristiwa pada zaman Nabi di mana para penduduk Khaibar melakukan transaksi kurma kualitas sempurna satu kilo dengan kurma kualitas rendah dua kilo, dua kilo dengan tiga kilo dan seterusnya. Praktik seperti ini dilarang Nabi Saw dan beliau mengatakan agar ketika menjual kurma kualitas rendah dibayar dengan harga sendiri, begitu pula ketika membeli kurma kualitas sempurna juga dengan harga sendiri.

Maksud hadis di atas, menurut Ibn alQayyim, adalah akad jual beli pertama dengan kedua harus dipisah. Jual beli kedua bukanlah menjadi syarat sempurnanya jual beli pertama, melainkan berdiri sendiri. Hadis di atas ditujukan agar dua akad itu dipisah, tidak saling berhubungan, apalagi saling bergantung satu dengan lainnya. (Ibnu alQayyim, tt: 238)

\section{Multi AkadMenyebabkan Jatuh ke Ribâ}

Setiap multi akad yang mengantarkan pada yang haram, seperti rib̂, hukumnya haram, meskipun akad-akad yang membangunnya adalah boleh. Penghimpunan beberapa akad yang hukum asalnya boleh namun membawanya kepada yang dilarang menyebabkan hukumnya menjadi dilarang. Hal ini terjadi seperti pada contoh:

1. Multi akad antara akad salaf dan jual beli

Dalam penjelasan sebelumnya bahwa Nabi melarang multi akad antara akad jual 
dan salaf. Larangan ini disebabkan karena upaya mencegah (sadd adz-dzarîah) jatuh kepada yang diharamkan berupa transaksi ribawi. Jumhur ulama melarang praktik multi akad ini, yakni terjadinya penghimpunan akad jual beli (mu'âwadhah) dengan pinjaman ( ardh) apabila dipersyaratkan. Jika transaksi multi akad ini terjadi secara tidak disengaja diperbolehkan karena tidak adanya rencana untuk melakukan qardh yang mengandung ribâa

2. Multi akad antara qardh dan hibah kepada pemberi pinjaman (muqridh) Ulama sepakat mengharamkan qardh yang dibarengi dengan persyaratan imbalan lebih, berupa hibah atau lainnya. Seperti contoh, seseorang meminjamkan (memberikan utang) suatu harta kepada orang lain, dengan syarat ia menempati rumah penerima pinjaman (muqtaridh), atau muqtaridh memberi hadiah kepada pemberi pinjaman, atau memberi tambahan kuantitas atau kualitas objek qardh saat mengembalikan. Transaksi seperti ini dilarang karena mengandung unsur ribâ ( Ibnu Qudamah, t.th.: 436) Apabila transaksi pinjam meminjam ini kemudian disertai hadiah atau kelebihan, tetapi dilakukan sendiri secara sukarela oleh orang yang diberi pinjaman, tanpa ada syarat dan kesepakatan sebelumnya hukumnya halal, karena tidak mengandung unsur riba di dalamnya.

\section{Multi Akad Terdiri dari Akad-Akad yang Akibat Hukummya Saling Bertolak Belakang atau Berlawanan}

Kalangan ulama Malikiyah mengharamkan multi akad antara akad-akad yang berbeda ketentuan hukumnya dan/atau akibat hukumnya saling berlawanan atau bertolak belakang. Larangan ini didasari atas larangan Nabi menggabungkan akad salaf dan jual beli. Dua akad ini mengandung hukum yang berbeda. Jual beli adalah kegiatan muamalah yang kental dengan nuansa dan upaya perhitungan untung-rugi, sedangkan salaf adalah kegiatan sosial yang mengedepankan aspek persaudaraan dan kasih sayang serta tujuan mulia. Karena itu, ulama Malikiyah melarang multi akad dari akad-akad yang berbeda hukumnya, seperti antara jual beli dengan ju'âlah, sharf, musâqah, syirkah, qirâdh, atau nikah (Al-Imrani, 2006 :181-182)

Meski demikian, sebagian ulama Malikiyah dan mayoritas ulama non-Malikiyah membolehkan multi akad jenis ini. Mereka beralasan perbedaan hukum dua akad tidak menyebabkan hilangnya keabsahan akad. (Ibnu Juzay, 2005 : 209) Dari dua pendapat ini, pendapat yang membolehkan multi akad jenis ini adalah pendapat yang unggul.

Larangan multi akad ini karena penghimpunan dua akad yang berbeda dalam syarat dan hukum menyebabkan tidak sinkronnya kewajiban dan hasil. Hal ini terjadi karena dua akad untuk satu objek dan satu waktu, sementara hukumnya berbeda. Sebagai contoh tergabungnya antara akad menghibahkan sesuatu dan menjualnya. Akad-akad yang berlawanan (mutadhâdah) inilah yang dilarang dihimpun dalam satu transaksi.

\section{Hukum Multi Akad}

Status hukum multi akad belum tentu sama dengan status hukum dari akad-akad yang membangunnya. Seperti contoh akad bai' dan salaf yang secara jelas dinyatakan keharamannya oleh Nabi Saw Akan tetapi jika kedua akad itu berdiri sendiri-sendiri, maka baik akad bai' maupun salaf diperbolehkan. Artinya, hukum multi akad tidak bisa semata dilihat dari hukum akad-akad yang membangunnya. Bisa jadi akadakad yang membangunnya adalah boleh ketika berdiri sendiri, namun menjadi haram ketika akad-akad itu terhimpun dalam satu transaksi.

Meski ada multi akad yang diharamkan, namun prinsip dari multi akad ini adalah boleh dan hukum dari multi akad diqiyaskan dengan hukum akad yang membangunnya. Artinya 
setiap muamalat yang menghimpun beberapa akad, hukumnya halal selama akad-akad yang membangunnya adalah boleh. Ketentuan ini memberi peluang pada pembuatan model transaksi yang mengandung multi akad.

Mengenai status hukum multi akad, ulama berbeda pendapat terutama berkaitan dengan hukum asalnya. Perbedaan ini menyangkut apakah multi akad sah dan diperbolehkan atau batal dan dilarang untuk dipraktikkan. Mengenai hal ini ulama berada dalam dua pendapat tersebut; membolehkan dan melarang.

Mayoritas ulama Hanâfiyah, sebagian pendapat ulama Malikiyah, ulama Syafi'iyah, dan Hanbali berpendapat bahwa hukum multi akad sah dan diperbolehkan menurut syariat Islam. Bagi yang membolehkan beralasan bahwa hukum asal dari akad adalah boleh dan sah, tidak diharamkan dan dibatalkan selama tidak ada dalil hukum yang mengharamkan atau membatalkannya (Al-Imrani, 2006: 69) Hukum asal dari syara' adalah bolehnya melakukan transaksi multi akad, selama setiap akad yang membangunnya ketika dilakukan sendiri-sendiri hukumnya boleh dan tidak ada dalil yang melarangnya. Ketika ada dalil yang melarang, maka dalil itu tidak diberlakukan secara umum, tetapi mengecualikan pada kasus yang diharamkan menurut dalil itu. Karena itu, kasus itu dikatakan sebagai pengecualian atas kaidah umum yang berlaku yaitu mengenai kebebasan melakukan akad dan menjalankan perjanjian yang telah disepakati. (Nazih hammad, 2005: 8)

\section{Penerapan Multi Akad di Perbankan Syariah dan Hukumnya}

Ada beberapa model pengembangan akad yang digunakan dalam produk perbankan syariah. Model tersebut diterapkan berdasarkan fatwa yang dikeluarkan oleh Dewan Syariah Nasional Majelis Ulama Indonesia. Model pengembangan akad yang disahkan fatwa DSN dalam bentuk kombinasi akad-akad. Kombinasi akad mengambil dua model, akad berganda (mujtami'ah) dan akad berbilang (muta'addidah). Penjelasan model tersebut adalah:

\section{Model Akad Tunggal}

Akad tunggal hanya mencakup satu akad dalam transaksi. (Al-Imrani, 2006: 33) Contoh akad tunggal adalah jual beli, sewa-menyewa, kerja sama (syirkah), salam, dan lain sebagainya. Jumlah akad tunggal yang digunakan dalam fatwa DSN sebanyak enam belas (16) akad. Akad tersebut meliputi wadî'ah, mudhârabah, murâbahah, salam, istishnâ', musyârakah, ijârah, wakâlah, kafâlah, hawâlah, qardh, hibah, rahn, sharf, ju'âlah, dan bay'. Akad tunggal digunakan antara dua pihak, yaitu antara nasabah dan lembaga keuangan syariah. Tabungan wadiah merupakan produk perbankan syariah yang menggunakan akad tunggal. Nasabah sebagai penitip dan perbankan syariah sebagai penerima titipan. Produk pembiayaan ijârah juga termasuk akad tunggal. Perbankan syariah berperan sebagai pemberi sewa dan nasabah sebagai penyewa.

\section{Model Akad Berganda (Mujtami'ah)}

Akad berganda (mujtami'ah, sebagian ahli fikih menyebutnya dengan akad murakkabah) adalah berhimpunnya beberapa akad dalam satu transaksi dengan cara dihimpun atau bertukar yang mana seluruh hak dan kewajiban dari akad tersebut dianggap sebagai akibat hukum satu transaksi. (Al-,Imrani, 2006: 46) Akibat hukum tersebut tidak bisa dipisah-pisah berdasarkan akad-akad yang membangunnya. (Nazih Hammad, 2005: 7) Termasuk dalam kategori akad berganda adalah terhimpunnya beberapa akad dalam satu transaksi seperti diterapkan dalam keuangan syariah modern dan syarat akad terhadap akad lainnya.

Contoh akad yang masuk dalam kategori akad berganda antara lain murâbahah, letter of credit syariah, kartu syariah (sharia card), mudhârabah musytarakah, dan musyârakah mutanâqishah. Hammâd memasukkan al- ijârah al-muntahiyah bil-tamlîk (IMBT) pada kategori 
akad berganda, namum menurut penulis akad tersebut masuk dalam kategori akad muta'addidah. Akad IMBT terdiri dari dua akad yang terpisah antara akad satu dan lainnya.

Murâbahah menurut Bank Indonesia adalah transaksi jual beli suatu barang sebesar harga perolehan barang ditambah dengan margin yang disepakati oleh para pihak, di mana penjual menginformasikan terlebih dahulu harga perolehan kepada pembeli. (Direktorat Perbankan Syariah, 2008: B6). Pengertian ini sama dalam fiqh yaitu jual beli dengan harga lebih dari harga jual beli pertama. Pihak yang berakad adalah penjual dan pembeli. Adapun murâbahah yang diterapkan di lembaga perbankan syariah adalah perpaduan antara dua jual beli dan janji. Jual beli pertama antara Perbankan syariah dan penyedia barang dan jual beli kedua antaranasabah dan pihak bank. Nasabah memesan suatu barang tertentu kepada bank syariah kemudian bank syariah membeli barang tersebut dari penyedia barang. Tahap selanjutnya bank syariah menjual barang tersebut kepada nasabah dengan harga perolehan ditambah keuntungan yang disepakati. Baik bank syariah dan nasabah saling berjanji untuk membeli barangsesuai pesanan. Bank syariah dapat menjual barang tersebut setelah barang dimiliki bank. Dua akad jual beli dan janji tersebut dilaksanakan dalam satu transaksi dan tidak terpisah. Dampak hukum transaksi tersebut satu yaitu beralihnya objek jual beli dari bank syariah ke nasabah. Dengan demikian akad murâbahah termasuk kategori akad berganda (mujtami'ah).

Kartu syariah mencakup kartu kredit (sharia card), kartu debit (sharia charge card), dan kartu bisnis (platinum). Kartu syariah adalah kartu yang dikeluarkan oleh lembaga perbankan syariah yang pemegangnya dapat melakukan transaksi untuk pengambilan uang tunai, pembelanjaan barang, bukti atau jaminan keuangan, dan layanan lainnya dengan menggunakan kartu tersebut.
Pihak yang terlibat dalam pengelolaan kartu syariah antara lain penerbit kartu, pemegang kartu, penerima kartu (merchant atau supplier), dan bank perantara (al-Imrani, 2005 : 355-356). Banyaknya pihak yang terlibat dalam kartu menuntut penggunaan akad-akad di antara para pihak tersebut. Fatwa DSN menetapkan setidaknya ada tiga akad yang digunakan yaitu kafâlah, ijârah, dan qardh. (DSN dan BI, 2006 : 18). Meskipun para pihak dan akad yang digunakan banyak, penandatanganan kontrak penggunaan kartu hanya dilakukan antara nasabah pemegang kartu dan penerbit kartu. Dengan demikian, penggunaan akad-akad tersebut memiliki akibat hukum satu yaitu kebolehan pemanfaatan kartu baik untuk pengambilan uang tunai atau pembelian barang. Transaksi melalui kartu syariah tersebut termasuk bentuk akad berganda.

Bentuk lain dari penggunaan akad berganda terlihat dari produk kombinasi mudhârabah musytarakah yang digunakan di perbankan syariah. Pada kombinasi akad ini, lembaga perbankan syariah yang berperan sebagai mudhârib atas dana-dana yang diserahkan nasabah (sebagai shâhib al-mâl) menyertakan modalnya untuk diinvestasikan kepada pihak ketiga (mudhârib). Perbankan syari'ah selain sebagai mudhârib juga sebagai shâhib al-mâl (Muhammad Utsman, 2001 : 375) Pihak yang terlibat adalah nasabah, perbankan syariah, dan pengelola dana. Dalam kontrak tersebut Perbankan syariah akan mendapatkan keuntungan ganda sebagai mudhârib dan shâhib al-mâl. Perbankan syariah juga menanggung kerugian sebagai shâhib al-mâl jika terjadi kegagalan usaha (Muhammad Utsman, 2001 : 375) Dalam hal nasabah sebagai mudhârib dan shâhib al-mâl sekaligus, maka perbankan syari'ah sebagai shâhib al-mâl saja. Nasabah akan mendapatkan porsi keuntungan sebagai mudhârib dan shâhib al-mâl. Prosedur demikian digunakan untuk produk pembiayaan syariah (DSN dan BI, 2006:330) Kontrak kombinasi 
tersebut harus mendapatkan izin dari shâhib almâl pertama (Wahbah al-Zuhaily, 2006 : 107) Kontrak tersebut termasuk akad berganda yang menggabungkan dua akad dalam satu transaksi.

\section{Model Akad Berbilang (Muta'addidah)}

Akad berbilang (muta'addidah) adalah akad yang berbilang dari sisi syarat, akad, pelaku, harga, objek, dan lain sebagainya. (Al-Imrani, 2005 : 49) Dua atau lebih akad yang dihimpun dalam satu transaksi namun terpisah antara satu akad dengan lainnya termasuk dalam kategori akad berbilang. (Al-Imrani, 2005 : 47) Perbedaan akad mujtami'ah dengan muta'addidah terletak pada keberadaan akadakad dan akibat hukumnya. Pada mujtami'ah akad-akad yang terhimpun tidak terpisah, sedangkan pada muta'addidah akad-akad terpisah antara satu dengan lainnya. Akibat hukum dari mujtami'ah adalah satu sedangkan dari muta'addidah adalah sebanyak akad yang membangunnya. Pada mujtami'ah akad- akad dijalankan sekaligus, sedangkan pada muta'addidah akad-akad dijalankan secara terpisah. Termasuk dalam kategori akad ini antara lain istishna' mawazy, salam mawazy, alijarah al-muntahiyah bil-tamlîk (IMBT), dan sale and lease back.

Istishna' mawazy dan salam mawazy merupakan perpaduan antara kontrak istishna'istishna' dan salam-salam. Kontrak tersebut digunakan antara tiga pihak, nasabah, perbankan syariah dan penyedia barang. Nasabah memesan barang dalam bentuk istishna' atau salam kepada perbankan syariah. Kemudian Perbankan syariah memesan lagi barang tersebut kepada penyedia barang. Kedua akad tersebut terpisah dan dilaksanakan sendiri-sendiri. (DSN dan BI, 2006: 143)

Al-ijarah al-muntahiyah bil-tamlik (IMBT) termasuk produk di perbankan syariah yang digunakan terutama untuk pembiayaan barang. IMBT adalah kontrak sewa-menyewa yang diakhiri dengan kepemilikan atas objek sewa tersebut. Praktiknya di perbankan syariah sebagai berikut; Perbankan syariah menyewakan suatu objek sewa kepada nasabah untuk waktu tertentu dengan harga sewa yang disepakati. Setelah masa sewa selesai dan semua cicilan dibayar, objek sewa tersebut beralih kepemilikannya kepada nasabah dengan menggunakan akad baru. Bedanya IMBT dan jual beli kredit terletak pada kepemilikan objek akad. Jika pada IMBT kepemilikan objek baru beralih setelah berakhirnya cicilan, sedangkan pada jual beli kredit kepemilikan telah berpindah sejak transaksi jual beli disepakati meskipun pembayarannya dicicil untuk jangka waktu tertentu.

Akad sale and lease back terutama digunakan pada produk Surat Berharga Syariah Negara (SBSN). Akad tersebut disahkan dalam fatwa DSN-MUI Nomor 71 dan 72 tahun 2008. Fatwa nomor 71 berkaitan dengan akad sale and lease back dan fatwa 72 mengatur SBSN Ijarah Sale and Lease Back. Sale and lease back adalah jual beli suatu aset yang kemudian pembeli menyewakan aset tersebut kepada penjual (DSN dan BI, 2006 :195) Akad yang digunakan dalam produk tersebut jual beli dan sewa. Di antara dua akad tersebut ada janji di antara para pihak untuk menjual dan membeli kembali objek yang dijual. Antara akad jual beli dan sewa terpisah. (DSN dan BI, 2006 :195) Produk ini untuk mengganti produk jual beli ganda yang dilarang oleh mayoritas ulama, yaitu jual beli inah (bay' al-'̂nah). Dalam jual beli 'inah, pihak pertama menjual barang kepada pihak kedua dengan harga tertentu, kemudian pihak kedua menjual lagi kepada pihak pertama dengan harga lebih tinggi atau rendah dari harga pertama. Jual beli pertama dilakukan dengan tunai dan jual beli kedua dilakukan secara tangguh.

Fatwa DSN mengantisipasi larangan jual beli 'înah dengan mengkombinasi jual beli dan sewa, bukan jual beli dengan jual beli. Opsi peralihan kembali objek sewa dalam fatwa DSN 
dilakukan melalui janji dua belah pihak untuk menjual dan membeli kembali objek akad yang telah dijual sebelumnya. Pemisahan akad tersebut menunjukkan dua akad dibuat secara berbilang (tidak terintegrasi dalam satu transaksi).

Menganalisa dari beberapa bentuk dari multi akad di atas,dapat disimpulkan bahwa modifikasi akad merupakan bagian dari ijtihâd agar akad-akad yang terdapat dalam figh dapat diterapkan pada transaksi modern. Kebolehan memodifikasi akad harus mendasarkan pada keabsahan berlakunya masing-masing akad yang membentuknya. Artinya, modifikasi akad dikatakan sah apabila rukun-rukun dan syaratsyarat akad yang membentuknya terpenuhi, di samping memperhatikan batasan-batasan yang ditetapkan hadis. Agar rukun-rukun dan syarat-syarat akad terpenuhi, maka beberapa akad tidak boleh melebur menjadi satu.

Untuk memodifikasi akad, perlu adanya pemberlakuan dua akad atau lebih. Pemberlakuan akad-akad tersebut biasanya dikaitkan dengan rencana penberlakuan produk tertentu oleh lembaga perbankan syari'ah. Dalam melakukan modifikasi akad, secara umum ada tiga kemungkinan yang dapat dilakukan, yaitu: Pertama, memberlakukan sesama akad yang bersifat komersial (mu'âwadlah). Kedua, memberlakukan akad yang bersifat komersial (mu'âwadhah) dengan akad derma (tabarru'). Dan ketiga, memberlakukan sesama akad yang bersifat derma (tabarru').

Multi akad hasil modifikasi merupakan bagian dari muamalah secara umum. Hukum asal muamalah adalah mubâh selama tidak ada dalil yang menunjukkan keharamannya. Ali alDîn Za'tari dalam Fiqh al-Mu'âmalah al-Mâliyah al-Muqâran mengatakan bahwa tidak ada larangan dalam syariah tentang penggabungan dua akad dalam satu transaksi, baik akad mu'âwadlah maupun akad tabarru'. Hal ini berdasarkan keumuman dalil-dalil yang memerintahkan untuk memenuhi syarat-syarat dan akad-akad (Agustianto,2016). Adapun dalil yang dapat digunakan untuk membolehkan multi akad adalah firman Allah dalam Q.S. alMầidah ayat 1:

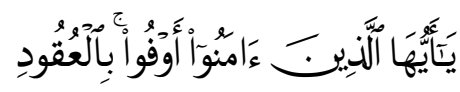

Hai orang-orang yang beriman, penuhilah aqad-aqad itu. (Q.S. al-Maidah [5]:1)

Dalam ayat ini Allah memerintahkan agar orang yang beriman menunaikan akad-akad mereka. Kata akad ini disebutkan secara umum karena tidak menunjuk pada akad tertentu. Artinya, semua akad yang telah memenuhi rukun-rukun dan syarat-syaratnya hukumnya sah, termasuk akad yang diberlakukan secara bersamaan (multi akad) baik yang bersifat alamiyah (al-'uqûd al-murakkabah al- thabî'îyah) maupun hasil modifikasi (al-'uqûd almurakkabah al-ta'dîlah).

Di samping ada dalil-dalil syara' yang melegitimasi berlakunya akad, namun ada beberapa ketentuan hadits yang perlu diperhatikan dalam memodifikasi akad. Menurut penulis, larangan dalam multi akad adalah terkait dengan penggabungan akad menjadi satu bukan pemberlakuan akadnya secara ganda (murakkab). DSN-MUI seringkali menegaskan bahwa suatu akad tidak boleh dikaitkan (mu'allaq) dengan akad yang lain.

Dari ketentuan tersebut dapat dipahami bahwa DSN-MUI secara tegas menolak multi akad bentuk uqud mutaqâbilah yaitu akad yang mengandung beberapa akad di mana satu akad dikaitkan (mu'allaq) dengan akad lain. Karena pemberlakuan akad secara ganda (multi akad) merupakan suatu keniscayaan, misalnya untuk pemberlakuan rahn akan selalu terangkai dengan qardh atau transaksi yang tidak tunai lainnya (bi al-dayn).

Ulama banyak berbeda pendapat dalam menafsirkan dua jual beli dalam satu akad. Pendapat yang paling dipilih (râjih) adalah yang menafsirkan bahwa seseorang yang menjual dengan harga kredit, kemudian 
mensyaratkan kepada pembelinya unjuk menjual kembali kepadanya dengan harga tunai.

Berdasarkan penjelasan tersebut, maka multi akad yang memberlakukan akad jual beli dengan akad hutang hukumnya dilarang. Meskipun ada multi akad yang dilarang, namun prinsip multi akad adalah boleh karena diqiyaskan dengan hukum akad yang membangunnya. Artinya setiap muamalat yang menghimpun beberapa akad hukumnya halal selama akad yang membangunnya adalah boleh. Ketentuan ini memberi peluang pada pembuatan transaksi yang mengandung multi akad. Menurut Nazih Hammad, kebolehan multi akad berlaku umum, sedangkan beberapa hadits Nabi maupun nash lain yang mengharamkan multi akad adalah ketentuan pengecualian. Hukum pengecualian tidak bisa diterapkan dalam segala praktik muâmalah yang mengandung multi akad. (Nazih Hammad, 2005 :11-12)

A-'Imrani memberi standar tentang multi akad yang diperbolehkan. Batasan multi akad menurutnya adalah tidak menyangkut masalah yang dilarang syariah, tidak bertentangan antara akad satu dengan akad lainnya, multi akad tidak membawa (mengakibatkan) kepada yang haram, multi akad tidak boleh antara akad yang berifat pertukaran (mu'âwadlah) dengan akad yang bersifat kebajikan (tabarru'), dan multi akad tidak menyebabkan kepada yang haram (AlImrani, 2006: 179-188)

Aspek yang tetap adalah pemeliharaan kemashlahatan. Maslahat yang didapat dengan mengkomodasi kebolehan multi akad (ta'addud al-'uqûd fi shafqah wâhidah) adalah ketika praktisi ekonomi dapat mengaplikasikan syariah sesuai dengan perkembangan zaman. Dengan aplikasi tersebut, sektor-sektor usaha syariah terpacu untuk berkembang dan mencakup. Sebaliknya, apabila multi akad tidak diperbolehkan, maka sektor-sektor usaha dengan sistem syariah dapat mengalami kesulitan/ kendala (mudlarah). Kemudian aspek yang berubah (mutaghayyirâh) adalah aspek cara, yakni Nabi Muhammad Saw melarang multi akad, sedangkan DSN-MUI membolehkan dengan syarat agar pelaksanaan multi akad tersebut memperhatikan standar yang ditentukan agar tidak mengandung ketidakjelasan (jahâlah), ketidakpastian manipulatif (gharar) dan ribâ. Dengan kata lain, DSN-MUI membolehkan multi akad selama terhindar dari ribâ, jahâlah dan gharar.

\section{PENUTUP}

Perkembangan produk lembaga perbankan di tengah masyarakat kontemporer terus menggelinding sehingga menjadi keharusan yang tidak mungkin dihindari sehingga memaksa ulama mengeluarkan fatwa melalui pendekatan multi akad (al-'uqûd almurakkabah) untuk melegitimasinya. Pemberlakuan multi akad dalam transaksasi modern adalah sebuah keniscayaan yang tujuannya untuk mengamalkan nilai-nilai syariat yang ada di balik akad tersebut. Ketentuan Sunnah terkait multi akad merupakan sebuah pengecualian yang tidak berlaku secara umum. Multi akad ada yang bersifat alamiah hukumnya boleh, misalnya pemberlakuan antara akad pokok seperti al- qardl dengan akad yang bersifat ikutan seperti al- rahn, al-hiwôlah, dan lainlain.

Sedangkan multi akad hasil modifikasi tidak dilarang selama dalam pemberlakuan akad tidak melanggar prinsip Sunnah terkait peleburan akad. Berdasarkan kenyataan tersebut, perdebatan figh bukan pada tataran multi akadnya yang telah menjadi keniscayaan, melainkan pada tataran cara memodifikasinya. Dapat disimpulkan bahwa keharaman multi akad pada dasarnya disebabkan oleh tiga hal: dilarang agama atau hîlah karena dapat menimbulkan ketidakpastian (gharar) dan ketidakjelasan (jahâlah), menjerumuskan ke praktik riba, dan multi akad yang menimbulkan akibat hukum yang bertentangan pada objek 
yang sama. Dengan kata lain, multi akad yang memenuhi prinsip syariah adalah multi akad yang memenuhi standar atau tetap (dhawâbith) sebagaimana telah dikemukakan.

\section{DAFTAR KEPUSTAKAAN}

Ahmad Warson Munawwir. 1997. Kamus Al-Munawwir Arab - Indonesia Terlengkap. Surabaya : Pustaka Progresif

Al-Zuhaili. 2006. Al-figh al-islâmi wa adillatuhu. Jakarta : Gema Insani

Ascarya. 2010. Akad dan Produk Bank Syariah. PT Raja Grafindo Persada. Jakarta.

Imrani, Abdullah bin Ahmad Abdullah. 2006. al Uqud al Maaliyah al $\mathrm{Mu-}$ rakkabah study figh Ta'shiliyah wa Tathbiqiyyah. Riyad: Dar Kunuz Elshabelia an Nasr wa Tausi'.

Louis Ma'luf. 1986. Al-Munjid fi al-Luqhah wa al-a'lam, Bayrut: Dar al-Mashriq.
Nazih Hammad. 2005. al-Uqud alMurakkabah fi al-Figh al-Islamiy, Damaskus : Dar al-Qalam.

Rachmat Syafe'i. 2006. Fiqih Muamalah. Pustaka Setia Bandung.

Shubhy Mahmashani. 1983. al-Nazariyyah al-Ammah lilmujibat wa al-Uqud fi alShari'ah al-ISlamiyyah, Bairut: Dar alIlm Lilmalayin,

Syamsul Anwar. 2007. Hukum Perjanjian Syariah. PT. Raja Grafindo Persada. Jakarta.

Tim Penyusun. 1996. Kamus Besar Bahasa Indonesia. Jakarta: Balai Pustaka.

Ttn.. 1986. Al-Munjid Fil Lughati. Beirut, Libanon : Darul Masyruq. 